Claudian thus pointedly and learnedly expresses his Furies' innovative place in the tradition. But et festas renders alio redundant and thus robs it of much of its force.

Indeed, et festas may have originated, like line 346, as an attempt to explain one of Claudian's allusive and compressed expressions (hair drinking wine, ill-omened torches shining alio lumine at a happy wedding). As before, textual variants suggest the confusion: aliae replaces alio in several manuscripts. ${ }^{21}$ Either attempted explanation could have found its way into Claudian's text first. The intrusion of line 346 would have required the subsequent insertion of a conjunction to join lines 346 and 347 . Alternatively, the change of infaustas to et faustas would have left one conjunction too many, creating a perceived lacuna for line 346 to fill. ${ }^{22}$ Finally, it does not seem implausible that an early reader of Claudian, armed with a knowledge of Classical Latin poetry and with some poetic talent of his own, might have solved all of Claudian's riddles at once and produced the current text in a single move.

The University of Western Ontario

KYLE GERVAIS

kgervai2@uwo.ca

doi:10.1017/S0009838820000208

\title{
JEROME, EP. 53.7 AND THE CENTONIST PROBA
}

sola scripturarum ars est, quam sibi omnes passim uindicent: 'scribimus indocti doctique poemata passim' [Hor. Epist. 2.1.117]. hanc garrula anus, hanc delirus senex, hanc soloecista uerbosus, hanc uniuersi praesumunt, lacerant, docent, antequam discant. alii adducto supercilio grandia uerba trutinantes inter mulierculas de sacris litteris philosophantur, alii discunt-pro pudor! - a feminis, quod uiros doceant, et, ne parum hoc sit, quadam facilitate uerborum, immo audacia disserunt aliis, quod ipsi non intellegunt. taceo de meis similibus, qui si forte ad scripturas sanctas post saeculares litteras uenerint et sermone conposito aurem populi mulserint, quicquid dixerint, hoc legem dei putant nec scire dignantur, quid prophetae, quid apostoli senserint, sed ad sensum suum incongrua aptant testimonia, quasi grande sit et non uitiosissimum dicendi genus deprauare sententias et ad uoluntatem suam scripturam trahere repugnantem. quasi non legerimus Homerocentonas et Vergiliocentonas ac non sic etiam Maronem sine Christo possimus dicere Christianum, quia scripserit: 'iam redit et uirgo, redeunt Saturnia regna, iam noua progenies caelo demittitur alto' [Verg. Ecl. 4.6-7], et patrem loquentem ad filium: 'nate, meae uires, mea magna potentia solus' [Verg. Aen. 1.664], et post uerba

21 This and ferunt for bibunt (and Reinhardt's ore for crine) may be added to leta for lene and to minantes for canentes to suggest persistent confusion with this image of the Furies at play.

${ }^{22}$ Interpolation via intrusive gloss or parallel is common enough, but a likely instance at Claud. Stil. 1.302-5 illustrates the process that could have occurred in our passage: line 304 quis Briareus aliis numero crescente lacertis entered the text as an elaboration on line 303 bracchia centum, leading to subsequent changes in lines 303 (non to quae) and 305 (possent to posset) to repair the syntax (see Gnilka [n. 14], 8-27 with further discussion by A. Coşkun in his review of Gnilka [BMCR 2001.11.17]). For interpolation to fill a perceived lacuna, see, for example, Tarrant (n. 1 [1987]), 288-9. The other generally accepted interpolations in $D R P$ were motivated by real or perceived lacunae: see Hall (n. 4), on 1.139-41 (lines 139 and 140 were each attempts to complete the syntax of lines 137ff. after the loss of lines 141-214 from part of the tradition) and Gruzelier (n. 3), on 2.118 (an attempt to bridge an abrupt scene transition, which reflects either a small lacuna or typical late antique style). 
saluatoris in cruce: 'talia perstabat memorans fixusque manebat' [Verg. Aen. 2.650]. puerilia sunt haec et circulatorum ludo similia, docere, quod ignores, immo, et cum stomacho loquar, nec hoc quidem scire, quod nescias. (Jer. Ep. 53.7)

In the preceding passage from a letter to Paulinus of Nola (A.D. c.394), ${ }^{1}$ Jerome criticizes the fact that everyone tries to interpret the scriptures. By means of example, he refers to the garrula anus ('babbling old woman'), the delirus senex ('deranged old man') and the soloecista uerbosus ('loquacious sophist'). Jerome mentions various misleading ways in which people engage with Christian exegesis. Some weigh pompous words in the presence of women and philosophize about the scriptures. Others learn from women what they should teach men and boldly explain to others what they have not understood themselves. Others, like Jerome himself, had a secular education before they turned to the scriptures. Such people deceive the ears of their audience with a contrived sermon without bothering about the intention of the prophets and the apostles. They distort the meaning of scripture and force it to their own will. In the light of this discussion about distorting the text's meaning and bending it according to the interpreter's wishes, Jerome introduces his comments about Homeric and Virgilian centos (Homerocentonas et Vergiliocentonas). Jerome quotes three Virgilian passages ( $E c l$. 4.6-7, Aen. 1.664 and 2.650) and claims that, regardless of how suggestive of or adaptable to Christian concepts Virgilian verses might be, Virgil cannot be labelled a Christian without Christ (sine Christo); Jerome deems this practice as childishness (puerilia) and similar to the trickery of charlatans (circulatorum ludo similia).

As the Virgilian passages (or parts of them; see below) quoted by Jerome are used by Proba in her cento, ${ }^{2}$ the majority of scholars argue that the garrula anus in Jerome's Letter is a reference to the centonist Proba. ${ }^{3}$ Admitting the satirical effect of the three fictitious figures that Jerome gives as an example of incompetent exegetes, Cullhed argues against this identification on the grounds that i) Jerome's point is not to single

\footnotetext{
${ }^{1}$ For the date, see D.E. Trout, 'The dates of the ordination of Paulinus of Bordeaux and of his departure for Nola', REAug 37 (1991), 237-60.

${ }^{2}$ It has been suggested that the writer of the Cento Probae is not Faltonia Betitia Proba, as had been widely held, but her granddaughter, Anicia Faltonia Proba: D. Shanzer, 'The anonymous Carmen contra paganos and the date and identity of the centonist Proba', REAug 32 (1986), 232-48; ead., 'The date and identity of the centonist Proba', RecAug 27 (1994), 75-96; T.D. Barnes, 'An urban prefect and his wife', $C Q 56$ (2006), 249-56. For an overview of the arguments for and against these two candidates, see S. Schottenius Cullhed, Proba the Prophet: The Christian Virgilian Cento of Faltonia Betitia Proba (Leiden and Boston, 2015), 22-3. However, the consensus for Faltonia Betitia Proba remains; see the thorough refutation of the arguments for Anicia Proba offered by Alan Cameron, The Last Pagans of Rome (New York and Oxford, 2011), 327-37.

${ }^{3} \mathrm{P}$. Courcelle, 'Les exégèses chrétiennes de la quatrième Églogue', REA 59 (1957), 294-319, at 310 n. 1; Shanzer (n. 2 [1986]), 239; C.P.E. Springer, 'Jerome and the cento of Proba', in E.A. Livingstone (ed.), Latin Authors (other than Augustine and his Opponents), Nachleben of the Fathers (Studia Patristica 28) (Leuven, 1993), 96-105, at 99-100; Shanzer (n. 2 [1994]), 82-3; Barnes (n. 2), 256; R. Green. 'Which Proba wrote the cento?', CQ 58 (2008), 264-76, at 274-5; Cameron (n. 2), 337; K.O. Sandnes, The Gospel 'According to Homer and Virgil': Cento and Canon (Leiden, 2011), 136; A. Pelttari, The Space that Remains: Reading Latin Poetry in Late Antiquity (Ithaca, 2014), 110. See also H. Sivan, 'Anician women, the cento of Proba, and aristocratic conversion in the fourth century', VChr 47 (1993), 140-57, at 141-2 with caveats. S. McGill, 'Virgil, Christianity, and the cento Probae', in J.H.D. Scourfield (ed.), Texts and Culture in Late Antiquity: Inheritance, Authority, and Change (Swansea, 2007), 173-94, at 189 n. 37, maintaining that Jerome directs his attack at Proba or certain interpretations of her text, avers that 'Jerome presents the garrula anus as an exaggerated type and for satirical effect, and that it is hazardous to identify a historical person behind her', while finding the reference to female teachers (cf. alii discunt-pro pudor! - a feminis, quod uiros doceant, Jer. Ep. 53.7) 'as a better place to look for historical personages'.
} 
out a specific person but instead to stress how common this practice of misinterpreting the Bible is, and ii) if we do identify the garrula anus as Proba, "why do we refrain from speculating about whom the delirius senex and the soloecista uerbosus represent?'4

This study has two main aims. The first is to emphasize, by highlighting the evidence from other early Christian interpretations of the Virgilian verses mentioned in Ep. 53.7, that Jerome's point is to show how common this practice is. Second, I will demonstrate through a comparison with parallel texts that the garrula anus is in effect a topos, employed throughout classical and late antique Christian literature including in Jerome, and, therefore, not a reference to a specific person.

\section{CHRISTIAN INTERPRETATION OF THE VIRGILIAN PASSAGES QUOTED IN JER. EP. 53.7}

Of the three passages cited in Jer. Ep. 53.7 (Ecl. 4.6-7, Aen. 1.664 and 2.650), only Aen. 2.650 is, so far as we know from the extant centos, uniquely used by Proba (= Cento Probae 624). Aen. 1.664 (= Cento Probae 403) is also found in the anonymous De Verbi Incarnatione 35. As for Ecl. 4.6-7, Proba employs only the first half-line of verse 7 (iam noua progenies = Cento Probae 34, followed by the second half of Aen. 7.680: omnis quem credidit aetas). Furthermore, Ecl. 4.6-7 exemplifies Jerome's point that there are Virgilian passages attracting Christian interpretations.

Virgil's Eclogue 4, which relates the advent of a miraculous child who will inaugurate a new era of bliss and prosperity, was readily subjected to Christian readings. ${ }^{5}$ Lines 6-7 speak of the return of the virgin, the return of Saturn's kingdom and the new offspring which will be sent from heaven. In Div. inst. 7.24, Lactantius describes a new Christian world that will follow Christ's Last Judgement, using imagery that the poets used to depict the Golden Age. Lactantius states that the poets spoke of this renewed Christian world as if it had existed in the past in the reign of Saturn. This misinterpretation on behalf of the poets stems from the fact that the prophets talked about future events as if they had already taken place. Subsequently, Lactantius quotes thirteen lines from Eclogue 4 (38-41, 28-30, 42-5, 21-2) that describe the Golden Age, and states that 'the poet said these things according to the verses of the Cymaean Sibyl'. Although here we do not have a direct reference to Ecl. 4.6-7, the Saturnia regna, mentioned in Ecl. 4.6 and described in the Virgilian passages quoted in Div. inst. 7.24, are for Lactantius a prophecy of a new Christian world that the poets took as something that had already been accomplished.

Elsewhere we find more specific references to Ecl. 4.6-7. In the Oratio ad coetum sanctorum 19 (A.D. 325), appended to Eusebius of Caesarea's Life of Constantine, Constantine quotes $E c l$. 4.5-6 (translated into Greek) and interprets the virgin referred

\footnotetext{
${ }^{4}$ Cullhed (n. 2), 57-8. J. Curran, 'Virgilizing Christianity in late antique Rome', in L. Grig and G. Kelly (edd.), Two Romes: Rome and Constantinople in Late Antiquity (Oxford, 2012), 325-44, at 341 , though he does not identify the three characters in Jer. Ep. 53.7 with specific persons, entertains the idea that 'Jerome's remarks were a general satirical swipe at several generations of confidently Christian Roman Petronii, a family which ... was notably proud of its own literary profile in the society of Rome'.

${ }^{5}$ Courcelle (n. 3); S. Benko, 'Virgil's fourth eclogue in Christian interpretation', ANRW 2.31.1 (1980), 646-705; C. Kallendorf, The Protean Virgil: Material and Form and the Reception of the Classics (Oxford, 2015), 48-58.
} 
to in iam redit et uirgo as the Virgin Mary. ${ }^{6}$ In his commentary on Eclogue 4, Philargyrius (late fourth / early fifth century or later) provides various interpretations for the characters that feature in lines 6-7. He states that the uirgo of Ecl. 4.6 can be either Iustitia or the Virgin Mary. ${ }^{7}$ Regarding the noua progenies (Ecl. 4.7), Philargyrius gives three different possibilities that some people (quidam) support: i) Christ, ii) Saloninus, the son of Asinius Pollio and iii) Octavian. ${ }^{8}$

The Christian readings of the lines of Eclogue 4 that Jerome quotes-even if put side by side with mythological or historical interpretations, as in the case of Philargyriusunderscore the susceptibility of Virgil's verses to a Christian interpretation and, thus, their suitability as components (membra) of a Virgilian cento. And that is confirmed in practice, as, in addition to Cento Probae 34, the first part of Ecl. 4.7 also occurs in two other late antique centos, De Verbi Incarnatione (60) and De ecclesia (21).

So, of the three Virgilian passages that Jerome mentions in Ep. 53.7, only Aen. 2.650 is used solely by Proba and not by any other cento writer that has come down to us. On the contrary, the texts we examined in this section show that the Virgilian verses quoted by Jerome prove exactly his point, that there are passages in the Virgilian corpus that are easily susceptible to a Christian interpretation. Jerome quoted these passages in order to highlight a general practice. In so doing, Jerome not only does not point to a specific person but in fact deters us from identifying a historical personality behind his three caricatures (garrula anus, delirus senex, soloecista uerbosus).

\section{GARRVLA ANVS AND THE 'OLD WIVES' TALES' TOPOS}

From early on in classical literature, old women often became associated with continuous and illogical verbiage. The 'old wives' tales' motif has been used in secular and in Christian traditions alike. ${ }^{9}$ It can be traced as far back as, on the one hand, Plato ${ }^{10}$ and, on the other, the Bible. ${ }^{11}$ In Late Antiquity, Latin writers (especially Christian ones) were especially fond of this topos. The adjective anilis ('old-womanish') coupled with the words superstitio and fabula became fixed expressions. ${ }^{12}$ Other expressions were also employed to describe the foolish prattling of old women. In Perist. 10.304-5,

\footnotetext{
${ }^{6}$ For the debate about the date and the authorship of the Oratio ad coetum sanctorum together with bibliography, see T.D. Barnes, Constantine: Dynasty, Religion and Power in the Later Roman Empire (Oxford, 2011), 112-20.

7 ideo Iustitia uirgo dicta est, eo quod incorrupta est, uel Maria (recensio I).

${ }^{8}$ NOVA PROGENIES idest quidam dicunt inspiratum eum de Saluatoris aduentu, quidam de aduentu Salonini Pollionis, quidam de aduentu Octauiani dixisse (recensio I).

${ }^{9}$ For an overview of the negative views towards old women's tales from antiquity through to the Middle Ages, see J. Ziolkowksi, 'Old wives' tales: classicism and anti-classicism from Apuleius to Chaucer', Journal of Medieval Latin 12 (2002), 90-113.

${ }^{10} \mathrm{Pl}$. Tht. 176b, Grg. 527a: see Ziolkowski (n. 9), 94-5.

11 Timothy 4.6-7: see Ziolkowski (n. 9), 100-1.

12 Ziolkowski (n. 9), 94. For anilis fabula, see e.g. Min. Fel. Oct. 11.2, 20.4 quid illas aniles fabulas de hominibus (i.e. human metamorphoses into various animals and flowers in the pagan tradition); Ambrose, Hex. 4.8.33, Off. 1.36 tibi autem, fili, contemptum diuitiarum, profanarum quoque et anilium fabularum suadet declinationem; Prudent. Perist. 9.18 non est inanis aut anilis fabula (the pictorial representation of Cassian's martyrdom); Paulinus of Nola, Ep. 16.4 ridiculam anilis fabulae cantilenam (the views of the Platonists); August. Vtil. cred. 1.2. For anilis superstitio, see Min. Fel. Oct. 13.5; Lactant. Diu. inst. 1.17 Romanae philosophiae princeps et amplissimo sacerdotio praeditus commenticios ac fictos deos arguit, quorum cultus superstitiones paene aniles esse testatur, 5.2, 5.13; Firm. Mat. Err. prof. rel. 17.4; Amm. Marc. 21.16.18.
} 
Prudentius has the martyr Romanus refer to pagan religious practices and beliefs as rancidae | edentularum cantilenae ('the mawkish babblings of toothless hags'). ${ }^{13}$ In his letter to Largus (Ep. 203), Augustine claims that lovers of earthly delights regard salutary admonitions as anilis cantilena ('old-womanish prattle').

Jerome often used the topos of the nonsensical babbling of old women in order to disparage rival views. ${ }^{14}$ In Contra Rufinum 3.22, Jerome sets the record straight about the circumstances of his departure from Rome to Bethlehem, and equates Rufinus' malevolent insinuations about it to anilium iurgiorum deliramenta ('the ravings of old-womanish quarrels'). In a similar way, in Contra Iohannem 14, Jerome disparages the views of John of Jerusalem as aniles et superfluae cantilenae ('old-womanish and superfluous prattle'). In the previous examples, Jerome uses the 'old wives' tales' topos in order to vilify the views of his opponents. Accordingly, he visualizes Vigilantius, one of his adversaries, making similar attacks against him (Contra Vigilantium 12). So, Vigilantius might smile at the thought that Jerome does not dare to enter the basilicas of the martyrs when being angry or having evil thoughts or having been beguiled by some phantom of the night, and might consider these superstitions as muliercularum deliramenta ('the fancies of common women').

In Ep. 53.7, Jerome refers to three different types (garrula anus, delirus senex, soloecista uerbosus), each propagating a false approach to the interpretation of scripture. Among these types is the garrula anus, a figure notorious for engaging in nonsensical prattling. In a similar vein, in Apotheosis 294-9, Prudentius instructs the heretic Sabellius (and his followers) to learn about God from a valid source and not from persons who spread unfounded and unreliable information. Prudentius enumerates various types that should not be trusted, among them the garrula nutrix ('babbling nurse', Apoth. 294).

In summary, the 'old wives' tales' topos is widely used in classical and late antique literature, and especially by Jerome. Set against this backdrop, it becomes obvious that in his reference to the garrula anus in Ep. 53.7 Jerome employs the same topos to disparage rival views and practices, a polemical strategy that, as we have seen, he often resorts to. In this instance, the rival practice is the misinterpretation of scripture. Given her literary precedent and her place as the first character in a parade of three exaggerated satirical figures, it is valid to say that the garrula anus is not a reference to a historical person but the embodiment of a stereotype.

\section{CONCLUSION}

There is no convincing link between Proba and the Virgilian verses quoted by Jerome in Ep. 53.7. On the contrary, what these verses prove is that there are passages in Virgil's œuvre that can be interpreted in a Christian manner, and that these passages are accordingly good candidates for finding their way into a Virgilian cento that describes episodes from the Bible. Furthermore, the garrula anus, who has often been taken to refer specifically to the centonist Proba, represents a topos often employed by late

${ }^{13}$ Cf. also Perist. 10.248-50: nonne pulmonem mouet | derisus istas intuens ineptias, | quas uinolentae somniis fingunt anus?

${ }^{14}$ M. Kahlos, 'Rhetorical strategies in Jerome's polemical works', in O. Wischmeyer and L. Scornaienchi (edd.), Polemik im Neuen Testament: Texte, Themen, Gattungen und Kontexte (Berlin, 2011), 621-49, at 624. 
antique Christian writers, not least Jerome. In other words, both the 'old wives' tales' topos and the Christian interpretation of (at least some) lines of Virgil are common. Therefore, not only do these not point to the centonist Proba (or to any other historical person for that matter) but rather underscore the stereotypical quality of the garrula anus and her exegetical practices. The garrula anus of Jer. Ep. 53.7 is as anonymous as the rest of the old women who offer their nonsensical tales in classical and late antique literature.

National and Kapodistrian University of Athens THOMAS TSARTSIDIS ttsar@phil.uoa.gr doi:10.1017/S000983882000021X

This is an Open Access article, distributed under the terms of the Creative Commons Attribution licence (http://creativecommons.org/licenses/by/4.0/), which permits unrestricted re-use, distribution, and reproduction in any medium, provided the original work is properly cited. 